\title{
Sanctions, Benefits, and Rights: Three Faces of Accountability
}

\author{
Merilee S. Grindle \\ CID Working Paper No. 205 \\ October 2010
}

(C) Copyright 2010 Merilee S. Grindle

and the President and Fellows of Harvard College

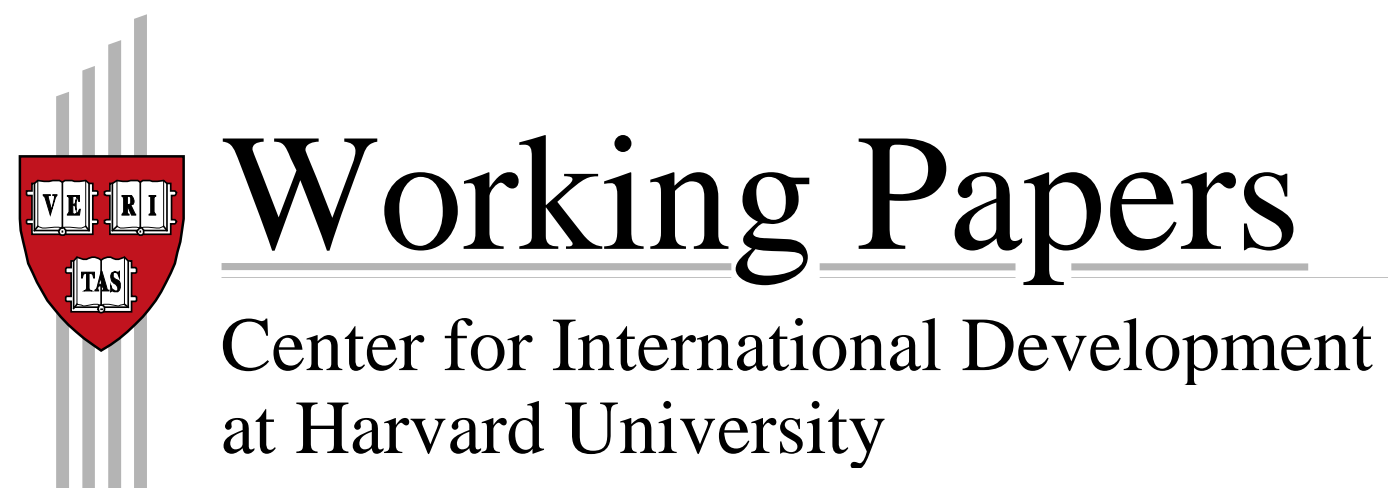




\title{
Sanctions, Benefits, and Rights: Three Faces of Accountability
}

\author{
Merilee S. Grindle
}

October, 2010

\begin{abstract}
As countries throughout the world democratize and decentralize, citizen participation in public life should increase. In this paper, I suggest that democratic participation in local government is enhanced when citizens can reply affirmatively to at least three questions about their ability to hold local officials accountable for their actions: Can citizens use the vote effectively to reward and punish the general or specific performance of local public officials and/or the parties they represent? Can citizens generate response to their collective needs from local governments? Can citizens be ensured of fair and equitable treatment from public agencies at local levels? The findings of a study of 30 randomly selected municipalities in Mexico indicate that, over the course of a decade and a half, voters were able to enforce alternation in power and the circulation of elites, but not necessarily to transmit unambiguous messages to public officials or parties about performance concerns. More definitively, citizens were able to build successfully on prior political experiences to extract benefits from local governments. At the same time, the ability to demand good performance of local government as a right of citizenship lagged behind other forms of accountability.
\end{abstract}




\section{Sanctions, Benefits, and Rights: Three Faces of Accountability Faculty Research Working Paper Series}

\section{Merilee Grindle}

Harvard Kennedy School

\section{J une 2010 RWP10-026}

\footnotetext{
The views expressed in the HKS Faculty Research Working Paper Series are those of the author(s) and do not necessarily reflect those of the John F. Kennedy School of Government or of Harvard University. Faculty Research Working Papers have not undergone formal review and approval. Such papers are included in this series to elicit feedback and to encourage debate on important public policy challenges. Copyright belongs to the author(s). Papers may be downloaded for personal use only.
} 


\title{
Sanctions, Benefits, and Rights: Three Faces of Accountability
}

\author{
Merilee S. Grindle \\ Harvard University \\ April 2010
}

As countries throughout the world democratize and decentralize, citizen participation in public life should increase. According to advocates of these trends, citizens in a decentralized and democratic system of government can expect enhanced opportunities to demand public attention for their needs, monitor government response to these demands, hold local officials responsible for their performance, and punish electorally those who do not deliver on promises or programs. Increased accountability of government to citizens, then, is a much-anticipated consequence of political, fiscal, and administrative decentralization in countries that are also democratizing. Felicitously, these trends are widely expected to improve the potential for government "by the people."

In this paper, I suggest that local government "by the people" is enhanced when citizens have access to at least three mechanisms for holding local officials accountable for their actions:

Can citizens use the vote effectively to reward and punish the general or specific performance of local public officials and/or the parties they represent?

Can citizens generate response to their collective needs from local governments?

Can citizens be ensured of fair and equitable treatment from public agencies at local levels?

In other words, to what extent do citizens have recourse to sanctions, benefits, and rights when local governments assume more responsibilities and political systems become more competitive?

The findings of a study of 30 randomly selected municipalities in Mexico indicate that, over the course of a decade and a half, voters were able to enforce alternation in power and the circulation of elites, but not necessarily to transmit unambiguous messages to public officials or parties about performance concerns. More definitively, citizens were able to build successfully on prior political experiences to extract benefits from local governments. At the same time, the ability to demand good performance of local government as a right of citizenship lagged behind other forms of accountability. The experience of Mexico also suggests that mechanisms to enforce the accountability of government to citizens evolve differentially in specific contexts. ${ }^{1}$ 


\section{Three Faces of Accountability in Theory and Practice}

Accountability refers to being answerable for actions. In democratic regimes, many accountability mechanisms work within government to set limits on the arbitrary exercise of power-constitutional guarantees enforced through courts, checks and balances in the separation of powers, independent auditing agencies, and federalism, for example. Other mechanisms enable citizens to constrain the activities of politicians, public officials, and public organizations. Three specific means through which citizens should be able to hold officials and agencies responsible are sanctions administered through elections, collective action to demand responsiveness to needs for public goods, and claims for citizenship rights. $^{2}$

Elections. With political decentralization, advocates of democratic reform anticipate that elections for local officials will enforce accountability by sanctioning public officials and the parties they represent, holding out the prize of electoral victory to those who perform well and the threat of defeat to those who are unresponsive or corrupt. States are more effective, they argue, as citizens have more opportunities to reward and punish the behavior of officials and parties. And, as a consequence of increased voter vigilance, rational politicians will have incentives to be responsive to local concerns. Political activists, non-governmental organizations, and human rights groups are similarly vocal in arguing that political decentralization increases the ability of citizens to select responsive public officials and to hold them accountable for their performance.

Collective Action. The capacity to influence allocative decisions of government through collective action is a second face of accountability, and also one that is expected to be enhanced through decentralization. Advocates of decentralization argue that it is easier for citizens to organize around common concerns locally than at other levels of government, where issues of collective action are more complex and common objectives more difficult to identify and act upon. Locally, citizens can readily define common interests in gaining access to public goods - in desiring to live in a community with potable water and drainage facilities, for example-and proximity and community ties encourage trust in undertaking collective actions to acquire such benefits. Further, citizens face relatively low transaction costs in organizing to influence local officials, certainly when compared to efforts to affect official behavior in far away capital cities and ministries.

Citizenship Rights. A third face of accountability is the ability to claim rights to certain standards of public performance. Disciples of public management anticipate that decentralization and democratization will produce more responsive decision-making, higher quality services, and public administrators motivated to perform well. When government administration is brought closer to those who receive services, they argue, beneficiaries of these services will become active in demanding good quality. Because those responsible for the quality of services are local, citizens will have incentives to complain and demand improvements if services fail or decline in quality. Moreover, public servants will have incentives to orient their behavior toward good service provision because of the potential for public disruption and complaints from dissatisfied 
“customers.” Corruption will also be more visible at local levels and thus easier to control.

How Effective Are these Mechanisms? These three mechanisms of accountability define expectations about relationships between state and society in decentralized and democratic settings. Yet simply altering the structural relationship among different levels of government and instituting democratic electoral procedures may not lead automatically or swiftly to greater accountability of government to its citizens. For example, the use of voting as a mechanism to sanction the behavior of officials and parties may depend on the extent to which "messages" about performance can be effectively conveyed through electoral results. Moreover, even at local levels, collective action cannot be taken for granted. Organizations that mediate effectively between government and individual citizens must agree on common interests, select leadership that can be successful in organizational and advocacy tasks, acquire information, and devise strategies to influence local officials and agencies. The third face of accountability, based on citizenship rights, may be dependent on the extent to which citizens have information about what they can and should expect in their encounters with government. In addition, citizens may or may not have a "culture" of accountability which sets their expectations about interactions with government or procedures through which to pursue equitable treatment when they believe they have not received it.

In subsequent pages, a comparative analysis of municipalities in Mexico suggests how citizens take advantage of new opportunities for holding government accountable for its performance and the extent to which their behavior is shaped by current and prior institutions and political practices. Beginning in the 1980s, the Mexican political system began a process of gradual democratization and decentralization and, by the mid-2000s, local governments in Mexico were the locus of increasing responsibility for local public life and increasingly competitive elections. These processes of gradual decentralization and democratization are briefly described in the following section of the paper. Then, data on thirty municipalities are examined for evidence of the ability of citizens to hold local governments accountable. The paper concludes with an assessment of the relationship between institutional changes and the roles that citizens have in holding local government accountable.

In the research reported here, a random sample of six states (one from each region of Mexico) was followed by a random sample of five medium-sized municipalities $(25,000$ to 100,000 inhabitants) in each state, for a total of thirty municipalities in the sample. ${ }^{3}$ During the summer and fall of 2004, researchers interviewed past and present officials in the thirty municipalities; delved into relevant documents about local fiscal conditions; explored the dynamics of changes in administrative, service, development, and participatory activities of local government; assessed the electoral history of each; generated insights into the relationship of local governments to state and federal ones; and came to know well the sites they were studying. ${ }^{4}$ In addition, data from national election archives and a 2002 municipal census are used to probe the relationship between accountability mechanisms and citizen capacity to regulate the performance of government. The results of this research shed light on ways in which citizens in 
Mexico's local political arenas were attempting to influence how local governments performed.

\section{Decentralization and Democratization in Mexico}

Municipalities in Mexico are equivalent to counties in the United States. They are generally composed of a town that serves as a county seat and its surrounding communities, which are often rural. ${ }^{5}$ Currently, local governments are responsible for basic municipal services including water, sewage, and public lighting, garbage, urban transport, public markets, roads and highways, public security, and slaughterhouses. They maintain social infrastructure, such as school buildings, playgrounds, health clinics, and hospitals. They regulate zoning and environmental issues. They have control over property taxes and can levy a series of local taxes and fees. Annually, they prepare budgets for approval by state legislatures. ${ }^{6}$

Local governments are composed of a mayor and councilors, who are elected for threeyear terms and who are legally barred from holding the same position again for three years. These officials are elected by party lists, with the first name on the ballot that of the candidate for mayor; proportional representation determines the make-up of the council. $^{7}$ In all municipal governments, mayors have extensive discretion over appointments of local administrative officials. Among the most important are heads of various departments - treasury, public works, public safety, culture and youth, public health, urban development, rural development, and so on. Mayors also appoint a chief administrative officer and the secretary of the government, who usually serves as chief of staff to the mayor. Beyond these high level positions, the mayor also usually can appoint sub-departmental officials, secretaries, office workers, laborers, and others.

Throughout most of the twentieth century, municipal governments were poor and almost powerless in the Mexican political and administrative system. Highly centralized, the country boasted a powerful executive, a weak legislature and judiciary, and a dominant party (the Partido Revolucionario Institucional, PRI) that won all presidential elections between 1929 and 2000, as well as the vast majority of legislative, state, and local elections. ${ }^{8}$ The system was held together by extensive clientelist networks that reached from the most remote locations to culminate in the presidential office; despite injustice and inequality, this system produced decades of a relative political peace that was the envy of politicians in many less stable countries. Beginning in the early 1980s, however, dual processes of decentralization (from above) and democratization (from above and below) introduced significant changes in how this system worked.

In the days of PRI hegemony, "the exercise of municipal government followed the rationale and orthodoxy of its role as a cog in the Mexican political (that is, PRI) machine." ${ }^{9}$ In the late 1980s, this tradition of local subservience to the PRI began to change, as the Partido Acción Nacional (PAN) and the Partido de la Revolución Democrática (PRD) began to make electoral inroads at state and municipal levels. ${ }^{10}$ As is clear in Figures 1 and 2, opposition party victories became increasingly common in Mexico. 
Figure 1

Percent of Municipalities and States Governed by Parties

Other than the PRI

1985-2003

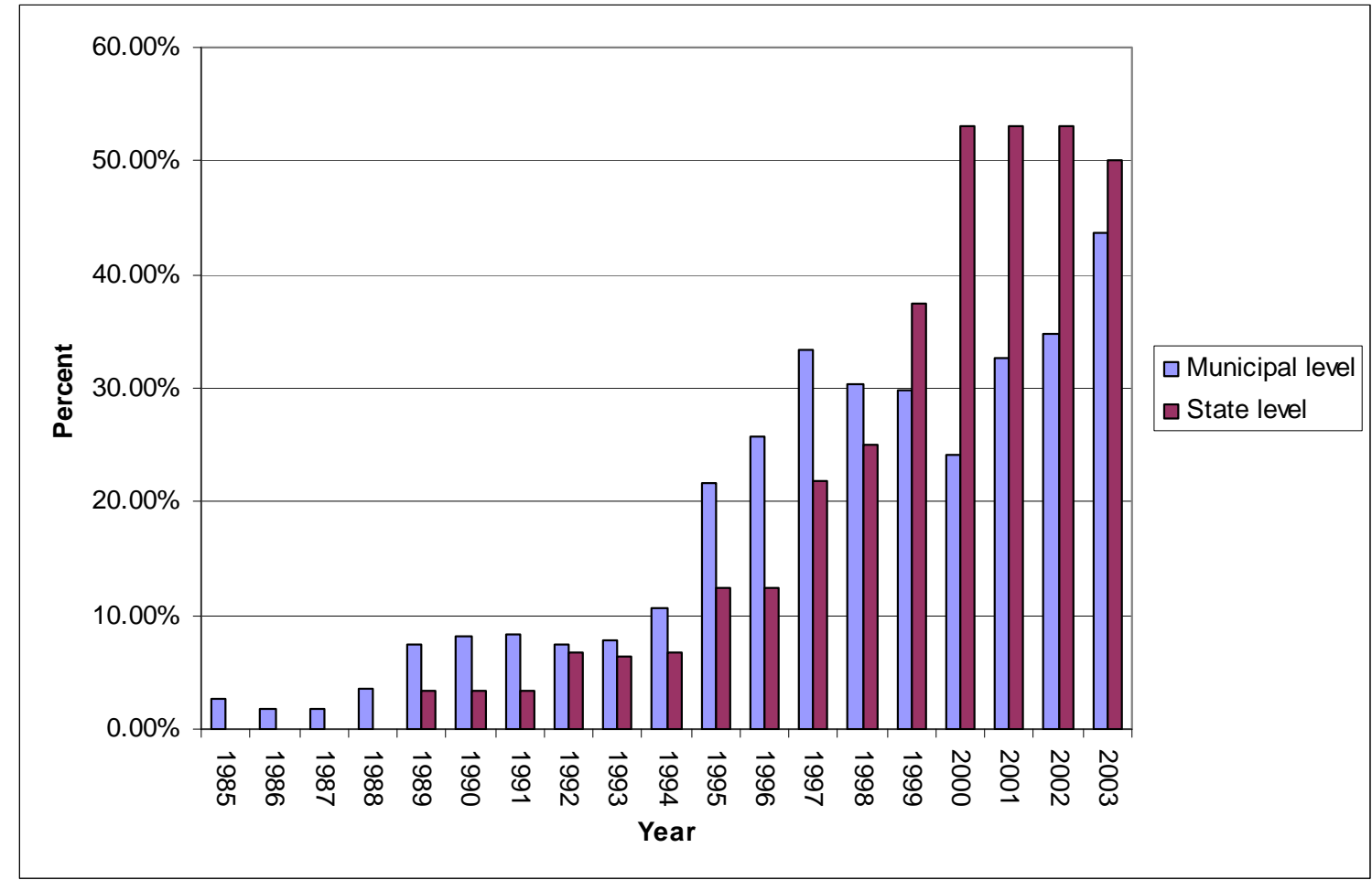

Source: CIDAC, www.cidac.org 
Figure 2

Percent of Municipal Population Governed by

Parties Other than the PRI

$1990-2003$

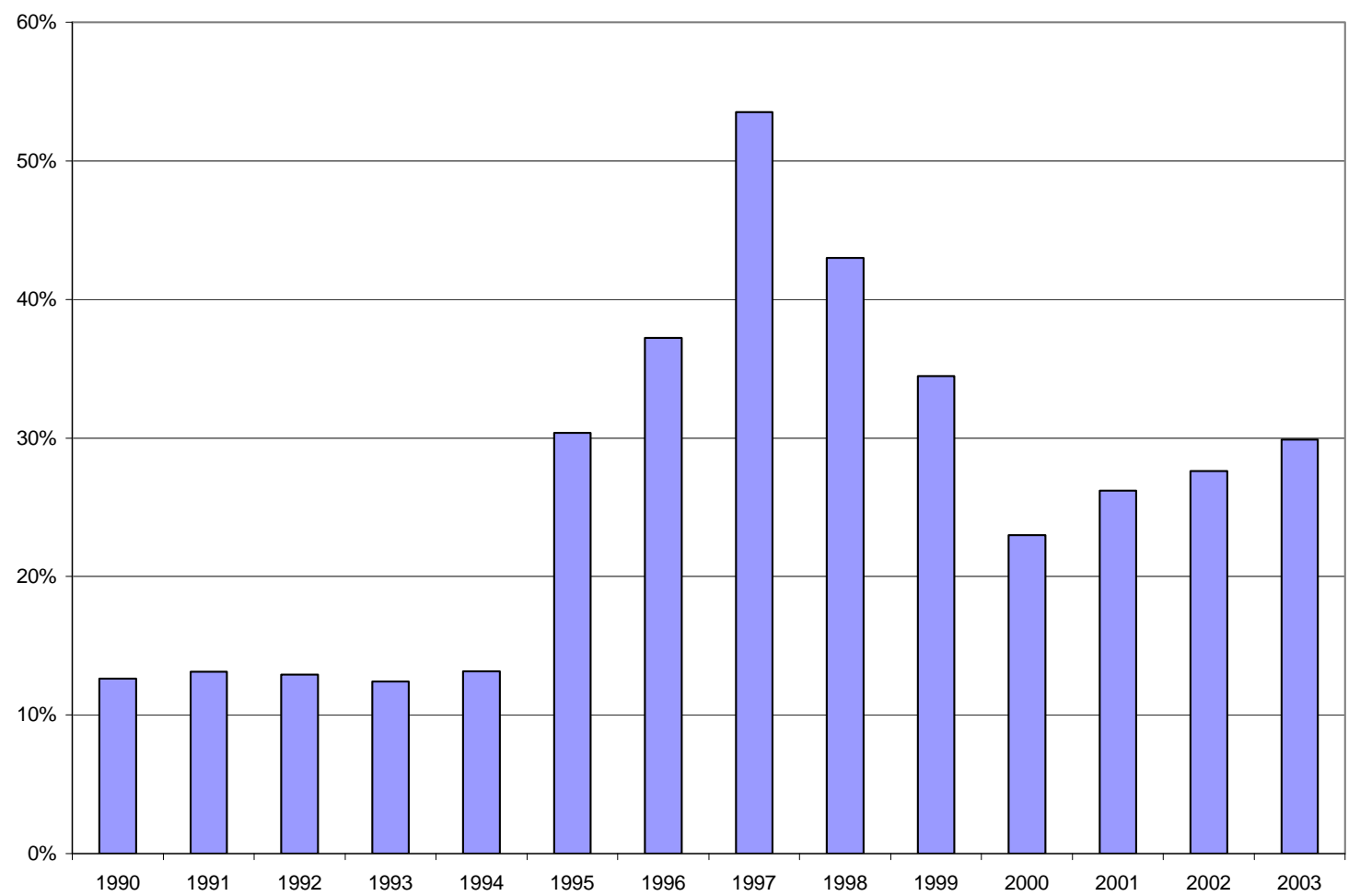

Source: INEGI, Sistema Municipal de Base de Datos

http://www.inegi.gob.mx/prod_serv/contenidos/espanol/simbad/default.asp?c=73

In addition, decentralization, initiated hesitantly in the early 1980s, and evolving equally hesitantly over the next two and a half decades, gradually allowed local governments greater autonomy and more resources. In 1994, they began to receive significant increases in grants and transfers from the federal government, by far the most important source of their revenue. ${ }^{11}$ Figure 3 shows the growth in funds provided to local governments from all federal sources between 1990 and 2002. In constant pesos of 1993, municipalities received extremely little before 1994; by 2002, they were receiving almost 2 percent of GDP. In per capita terms, there was an increase from 0.14 pesos per person in 1990 to 311.58 pesos in 2002 (see Table 1). 
Figure 3

Federal Transfers to All Municipal Governments (Millions of 1993 pesos)

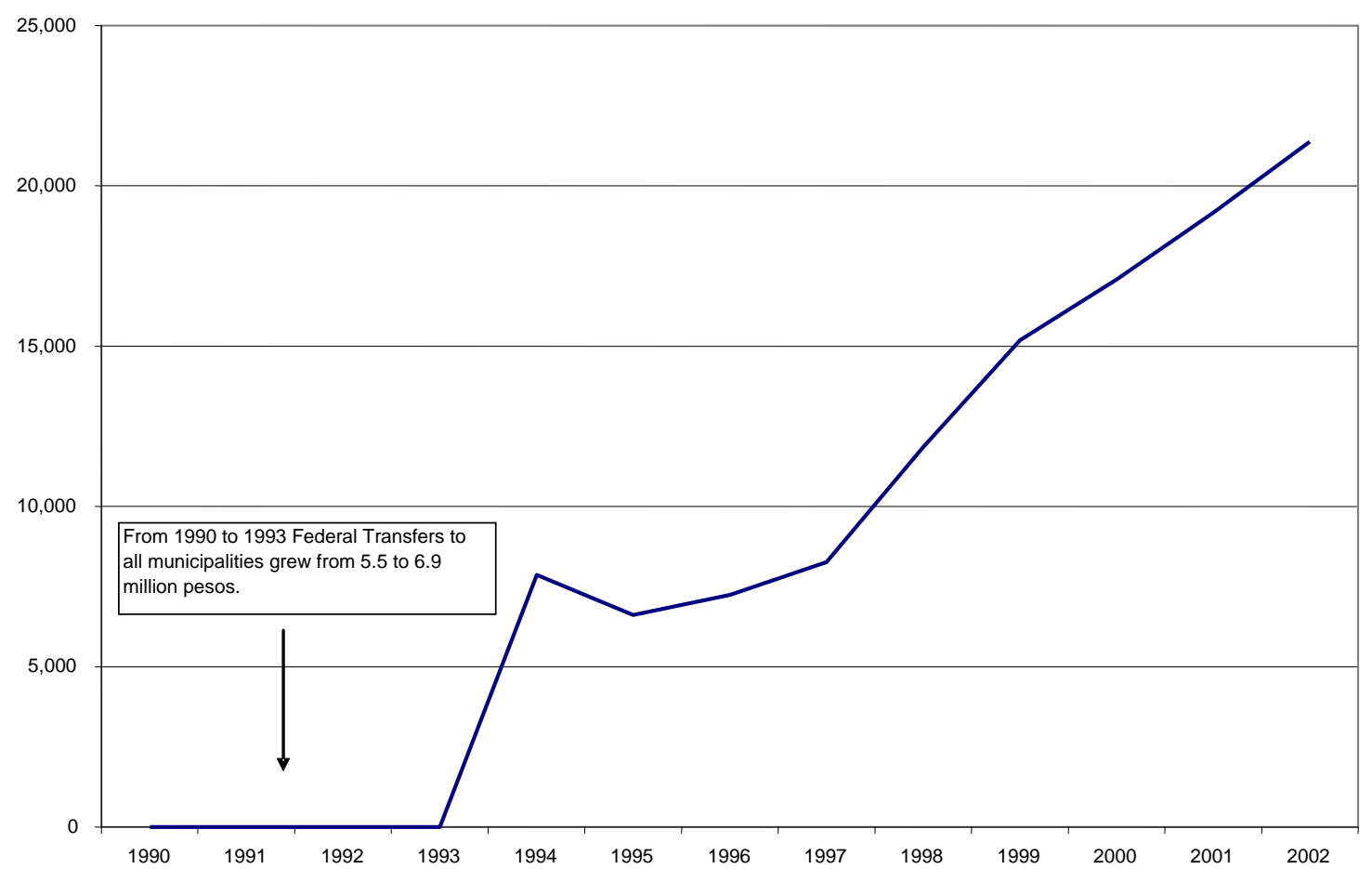

Source: INEGI, Sistema Municipal de Base de Datos

http://www.inegi.gob.mx/prod_serv/contenidos/espanol/simbad/default.asp?c=73

\section{Table 1}

Total Funding of Municipal Governments

1990-2002

(1993 Pesos)

\begin{tabular}{|c|c|c|c|}
\hline Year & \multicolumn{1}{|c|}{ Total } & $\begin{array}{c}\text { As \% } \\
\text { Of GDP }\end{array}$ & $\begin{array}{c}\text { Per Capita } \\
\text { (pesos) }\end{array}$ \\
\hline \hline 1990 & $11,493,530$ & 0.00 & 0.14 \\
1991 & $12,844,330$ & 0.00 & 0.15 \\
1992 & $13,957,728$ & 0.00 & 0.16 \\
1993 & $15,670,364$ & 0.00 & 0.18 \\
1994 & $16,627,876,932$ & 1.27 & 185.69 \\
1995 & $13,467,271,150$ & 1.10 & 147.76 \\
1996 & $13,593,322,125$ & 1.05 & 146.84 \\
1997 & $14,834,650,367$ & 1.08 & 157.94 \\
1998 & $19,041,518,428$ & 1.31 & 199.91 \\
1999 & $22,914,372,452$ & 1.53 & 237.25 \\
2000 & $24,847,462,509$ & 1.55 & 253.63 \\
2001 & $27,730,706,387$ & 1.73 & 279.05 \\
2002 & $31,412,724,549$ & 1.98 & 311.58 \\
\hline
\end{tabular}


Source: INEGI, Sistema Municipal de Base de Datos

http://www.inegi.gob.mx/prod_serv/contenidos/espanol/simbad/default.asp?c=7

$\underline{3}$ and Banco de Mexico,

http://www.banxico.org.mx/eInfoFinaciera/FSinfoFinanciera.html

Gradually, then, municipal elections in Mexico became arenas for greater competition among political parties and, by the mid-1990s, local governments were beginning to receive extensive new resources for the management of public affairs. This set the stage for the potential to increase citizen participation through elections, collective action, and expectations for government performance.

Voting to Reward and Punish. Over time, parties other than the PRI increased their capacity to win elections in the thirty research municipalities. Indeed, in these localities, the probability of an incumbent party losing control over town hall had risen from .06 in 1990 to .50 by 2004, even though incumbents routinely benefited from municipal funds and logistical support for their campaigns. Even where the PRI continued to reign supreme, its margin of victory was considerably reduced. Table 2 shows the increasing threat faced by the PRI at election time in the research municipalities, demonstrating that party's losses and also a pattern of decreasing margins of victory. As indicated, in 18 of the thirty, the PRI had lost at least one election; in only seven of them had opposition parties not come within a 10-point margin of the dominant party. Even in traditional strongholds of the PRI, such as the southern state of Oaxaca and the east central state of Puebla, opposition victories occurred or became more likely by the mid 1990s.

Table 2

The Threat of Electoral Loss: Increasing Competition for the PRI in Municipal Elections $1980-2004$

\begin{tabular}{|c|c|c|c|c|c|c|}
\hline & Municipio & $\begin{array}{c}\text { First time } \\
\text { PRI } \\
<60 \%\end{array}$ & $\begin{array}{c}\text { First time } \\
\text { PRI } \\
<50 \%\end{array}$ & $\begin{array}{c}\text { First time } \\
\text { with }<10 \% \\
\text { from its } \\
\text { closest } \\
\text { opponent } \\
\end{array}$ & $\begin{array}{c}\text { \# of PRI } \\
\text { losses }\end{array}$ & $\begin{array}{c}\text { Parties in } \\
\text { office at } \\
\text { time of } \\
\text { research }\end{array}$ \\
\hline \multirow{5}{*}{ Guanajuato } & Abasolo & 1982 & 1991 & 1991 & 2 & PAN \\
\hline & Manuel Doblado & 1991 & 2003 & 2003 & 1 & PAN \\
\hline & San Luis de la Paz & 1988 & 1991 & 1988 & 2 & PAN \\
\hline & Santa Cruz de Juventino R & 1991 & 1997 & 2000 & 1 & PVEM \\
\hline & Yuriria & 1991 & 1997 & 1997 & 2 & PAN \\
\hline \multirow{5}{*}{ Oaxaca } & Acatlán de Pérez Figueroa & 1992 & 1992 & 1992 & 1 & PRI \\
\hline & San Juan Guichicovi & 1992 & 1995 & 1995 & 0 & PRI \\
\hline & Santiago Pinotepa N. & 1995 & 1995 & 1995 & 1 & PRI \\
\hline & Santiago Juxtlahuaca & 1995 & 1995 & 1995 & 0 & PRI \\
\hline & Santo Domingo T. & 1980 & 1995 & 1995 & 0 & PRI \\
\hline \multirow{5}{*}{ Puebla } & Chignahuapan & 2001 & 2001 & - & 1 & PAN \\
\hline & Coronango & 1983 & 1992 & 1995 & 1 & PRI \\
\hline & Ixtacamaxtitlan & 1995 & 2001 & 2001 & 0 & PRI \\
\hline & Libres & 1995 & 1995 & 1995 & 0 & PRI \\
\hline & San Pedro Cholula & 1992 & 1995 & 1995 & 1 & PRI \\
\hline Sinaloa & Escuinapa & 1992 & 1992 & 1992 & 2 & PAN \\
\hline
\end{tabular}




\begin{tabular}{|c|c|c|c|c|c|c|}
\hline & Mocorito & 1995 & 1995 & 1995 & 0 & PRI \\
\hline & Rosario & 1995 & 1995 & 1998 & 1 & PRD \\
\hline & Salvador Alvarado & 1992 & 1992 & 1995 & 1 & PRI \\
\hline & San Ignacio & 1998 & - & - & 0 & PRI \\
\hline \multirow{5}{*}{ Tamaulipas } & Aldama & 1995 & 1995 & - & 0 & PRI \\
\hline & Gonzalez & 1995 & 1995 & 1998 & 0 & PRI \\
\hline & Miguel Aleman & 1995 & 1995 & 1995 & 1 & PAN \\
\hline & San Fernando & 1995 & 1995 & - & 0 & PRI \\
\hline & Tula & 1995 & - & - & 0 & PRI \\
\hline \multirow{5}{*}{ Yucatan } & Oxkutzcab & 1993 & 1995 & 1995 & 3 & PRI (PAN) \\
\hline & Progreso & 1993 & - & - & 0 & PRI (PRI) \\
\hline & Ticul & 1993 & 1995 & 1995 & 2 & PRI (PAN) \\
\hline & Uman & 1990 & 1995 & 1995 & 1 & PRI (PRI) \\
\hline & Valladolid & 1993 & 2001 & 1995 & 1 & PRI (PRD) \\
\hline
\end{tabular}

Source: CIDAC and Local Electoral Institutes

The threat of electoral loss was important in "forcing the parties to modernize themselves," a factor that was perhaps most true for the PRI. ${ }^{12}$ While there continued to be complaints that the PRI had not changed its colors from the old days of its dominance, most informants referred to elections in which the PRI won with lower margins of victory as "a wake up call” for the party. A PRIista administrator, for example, observed that “suddenly, we didn't have the power we had had for decades," and in a staunch PRI municipality, a local party president asserted that in the previous election, it was clear that "the people have given a vote of confidence to the PRI for the last time."13

Parties responded to increased competition by introducing important organizational and behavioral changes. In contrast to the days of PRI hegemony when the governor or the local political boss determined who would stand for election by appointing candidates, more democratic internal party processes often evolved. ${ }^{14}$ In Tamaulipas, for example, the PRI state party council ceded more authority to its local organizations in selecting candidates, a change from the old days when the governor made such choices. ${ }^{15}$ Contending leadership candidates in many localities were presented and voted upon by the membership of the party. Frequently, losing pre-candidates were offered positions on the list of candidates for the council. A former PRI mayor commented that since 1989, "the population has realized that it was possible to participate more actively. Now the PRI is more open, there's more internal competition, and the credentials of its leaders are clearer." 16

The threat of losing elections encouraged another development in the parties - they began to pay more attention to selecting candidates they hoped would be appealing to local voters. At times, the means for doing so contributed to internal democratic practices. After losing a municipal election in a traditional PRI stronghold in Tamaulipas, for example, that party organized a broad consultation with its voter base to select its next candidate for mayor. ${ }^{17}$ In Puebla, a municipal party began carrying out voter surveys to determine the popularity of potential candidates. ${ }^{18}$ A deeply divided PAN in a Oaxacan 
municipality sought to overcome its inability to win elections by selecting a candidate who was well respected in the community but not affiliated with any party. ${ }^{19}$ The PRI in some locations began to rejuvenate itself by drawing new and younger members into local party decision-making councils.

Increased competition was an important factor in altering the internal dynamics of the parties and, in many cases, encouraging them to adopt more democratic processes in selecting their candidates for public office. Modernizing the internal workings of the parties did not dramatically affect how campaigns were carried out, however. Instead, campaigning in a multiparty Mexico closely resembled campaigns in the old dominant party Mexico. Continuing practices from the days of PRI hegemony, for example, promises of jobs were the most important way to recruit campaign workers. ${ }^{20}$ As a consequence, when campaigns were underway, town halls tended to resemble ghost towns, as elected and appointed officials absented themselves to work for their candidates.

As in traditional campaigns of the PRI, party platforms were not important means for generating votes for local offices. In the thirty municipalities, campaign slogans focused on vague promises of a better future-among them "Working Shoulder to Shoulder," "A Government that Works for You" and "Working Together for a Better Municipality."21 Specific promises for attention to very specific public goods - a better access road to the community, potable water and electricity, drainage, a new bridge-were the stuff of daily campaigning. Equally important were individual promises for a job, a water hook-up, a new roof for a house. Thus, as in the past under the long reign of the PRI, community level political rallies were complemented by a great deal of one-on-one campaigning and listening to the individual grievances of citizens. In the research municipalities, candidates visited as many homes and localities as possible during a campaign, listening to problems and promising to resolve them when the candidate won. Significant numbers of citizens helped organize rallies and marches, put up signs, and worked to get out the vote for their candidates. Parties also sent their activists out to do surveys and to report back on what local communities were most concerned about. Campaigning in a more electorally competitive Mexico, then, mirrored a long tradition of labor-intensive retailing of promises and candidates.

Beyond promises, candidates brought gifts to potential voters. To demonstrate their sincerity, for example, they might bring paint for the local school and set local party activists to work painting it, or distribute sports equipment to community clubs or schools. Again, individual benefits, such as those distributed in the days of PRI dominance, were important for attracting voters - a chit for medicine from a local pharmacy or food from a local store, cement blocks for housing, free seeds and gasoline, for example. In the case of highly competitive elections, the amount of patronage and clientelistic practices might even have increased.

These pre-election gifts led to widespread charges of electoral fraud and vote buying. In one municipality, it was asserted that candidates could buy a vote for about $\$ 20$; elsewhere votes were reputed to cost between $\$ 15$ and $\$ 25{ }^{22}$ Frequently, also, 
incumbent parties were accused of using municipal funds for the campaigns of their candidates; similarly, incumbents were not above hoarding municipal funds so they could be spent on social services and public works just prior to elections. ${ }^{23}$ And charges of electoral fraud, common enough during the heyday of PRI ascendance, were also part of the more competitive electoral arena. On a more positive note, this form of campaigning did much to educate candidates about the needs and desires of their constituents. In addition, unconstrained by party platforms, parties could alter their priorities from one election to the next. Thus, for example, "In the last election, the candidates promised a university, more health clinics, school lunches, handouts, and cement blocks. This year, the people are worried about roads, jobs, and seeds for their crops." ${ }^{24}$

The strong tradition of retail campaigning meant that winning parties usually arrived in town hall without a clear program of government or even a mandate about important issues they should tackle. Programs were typically crafted once newcomers had arrived in municipal offices and, at times, no consistent programs at all were developed. Universally, the bulk of decision-making revolved around the allocation of public works to different parts of the municipality and appointments for jobs in town hall. Roads, drainage ditches, small bridges, potable water, electricity, a new clinic or hospital, parks, basketball courts, ring roads, a new school, tourist facilities, industrial parks-mayors focused great attention on the legacy of works they would leave behind when their administrations were over. Moreover, when competitive campaigns left behind divided councils, incumbents often encountered significant conflict over the allocation of resources and jobs. Such conflict could stand in the way of improved performance even if local leaders were committed to better governance.

Also, because of limitations on the re-election of mayors and councilors, individual office-holders could not be sanctioned directly unless they were seeking other positions through elections. That is, if a mayor wished to continue his or her career by running for office as a representative to the state or federal legislature, local citizens would have the capacity to sanction his actions while he had been mayor. If he decided to retire from public life, or to seek an appointive position, however, there was no direct way to sanction publicly his behavior. Similarly, with only about a third of municipal workers in unions that prevented their dismissal when new administrations took over, with no civil service, and with no immediate re-election providing for some continuity of personnel, changes of administration were characterized by wholesale changes in who had jobs in town hall. The skills and perspectives of those who were selected again depended on the preferences of the mayor. Where mayors had a personal concern for professionalizing local government, they appointed well-qualified officials; there was little to deter them from appointing relatives and cronies, however.

Potentially, of course, this does not mean that elections could not be used to send a message about the performance of a political party, but, as we have seen, the tendency toward retail politics and the capacity to emphasize the personality of the candidate generally undermined the ability to send a clear message to parties about good and bad performance. 
Organizing to Acquire Benefits. Despite a lively history of revolution, insurrection, and political mobilization, Mexico's $20^{\text {th }}$ century political system discouraged the emergence of a vibrant and independent civil society. For most of this period, the dominant theme in national politics and administration was centralization of authority and decision making in a national government that was held tightly together by a dominant national political party. Citizen demands were routinely met with clientelistic responses channeled through the PRI - in the case of peasant, worker, and middle class concerns - and with accommodation and mutual interest between government and economic elites. Important decisions were made at national levels, usually by the powerful executive branch, in ways that increased the importance of the national leaders of organized interests and, in many cases, encouraged an alignment of their interests with the strength and persistence of a centralized and authoritarian government.

At local levels, where organization around common interests for civic purposes might be easier to accomplish, Mexican politics generally provided little incentive for such action. Local officials and governments controlled few resources and did not have significant decision making power; local elites frequently used their ties to the PRI or organized interests to extract personal benefits from government and maintained control of local populations through clientelist networks that originated at the national level. There were not, in fact, many policies or actions local citizens could influence locally.

Of course, there were events in Mexico's history that attested to greater potential for effective citizen action. Certainly the Mexican Revolution of 1910 demonstrated a significant capacity of a very wide range of groups to mobilize for political and military purposes. After the consolidation of the PRI-dominated system, strikes, marches, and protests of various kinds were not unusual, despite the degree to which this system maintained a long-lasting, if inequitable, political peace. A student uprising in the late 1960s became emblematic of protest against the strictures of party-government and authoritarian decision-making.

In addition, in some regions of the country, indigenous groups were able to maintain traditions of local decision-making and action, although this too was frequently denatured through clientelistic relationships with political bosses. Then, after 1980, middle class groups began to demand more local control and resources for dealing with issues of development and the environment, indigenous groups pressed for recognition of traditional rights and greater autonomy, other groups organized around demands for security, jobs, and human rights, and many increasingly demanded an end to the dominance of the PRI. ${ }^{25}$ At the same time, government programs also began more consistently to include opportunities for local participation in programs and projects targeted for local areas. ${ }^{26}$

Nevertheless, the general pattern for state-society interaction in the $20^{\text {th }}$ century was one in which the state was dominant and civil society groups were dealt with in corporatist, clientelistic, and non-democratic ways, and in which overt repression was always available as a last resort. As a result, civil society was neither strong nor very independent at the outset of the $21^{\text {st }}$ century in Mexico. A generalized expectation of a 
weak and often disorganized civil society often pervaded public discussion of statesociety relations, even after the country's politics had become more democratic.

These expectations, however, did not capture the full reality of citizen engagement in the research municipalities. In fact, many of the municipalities boasted local community groups such as Lions Clubs and Rotary Clubs, professional associations of lawyers and doctors, producer's associations, and a variety of cultural organizations. In many, groups of citizens had joined together to establish and maintain a local history museum. Local improvement committees were ubiquitous. These were organized at the neighborhood or village level to increase the availability of public amenities such as roads, potable water, sewerage, and electricity.

Indeed, in all of the 30 research municipalities, there were organizations formed explicitly for the purposes of proposing, assisting in, and monitoring local investment projects. Among the most common patterns of local organization was that resulting from official requisites for acquiring benefits from other levels of government. ${ }^{27}$ National and state laws required each municipality to have a municipal development committee (CDM) whose purpose was to establish priorities for investments and to monitor their execution. In many places, the meetings of the CDM were preceded by community level meetings in which residents drew up petitions for public investments in their neighborhoods or villages. Creating a municipal development plan was supposed to be a major requisite for acquiring various project funds from state and national level agencies.

Investments made in particular kinds of activities — a new health clinic, for example, or a school rehabilitation project-also required the formation of citizen groups if funds were to be released by public agencies. In many cases, such committees were formed by municipal directors of various offices, such as public health or public works, and often served as participatory "window dressing" for decisions made elsewhere. In a municipality in Sinaloa, for example, an important local citizen remembered being asked to serve on a committee for public security.

After the committee was composed, we did an extensive analysis of the needs of the municipality and I developed plans for constructing police kiosks, we figured out routes for patrol cars, and we laid out needs for capacity building among the police officers. Well then, when we presented our report to the mayor, he told us it wouldn't be possible to carry out any of them because there wasn't any money. And so he told all the groups. As a consequence, the people who make up the committees get discouraged because they see that the mayors already have their security plan....Many times, when these committees are formed, an official photograph is taken, and then they never meet again. ${ }^{28}$

There were, however, examples in which municipal development committees became more authentic drivers of collective action. In a municipality in Oaxaca, for example, the CDM met one Sunday a month from 10:00 a.m. until 4:00 in the afternoon and reported average attendances of two to three hundred people. ${ }^{29}$ In a municipality in Tamaulipas, 60 to 70 people met as the municipal development committee every six months; after the 
initial priority-setting meeting, subsequent gatherings were dedicated to follow-up and review of progress. In another Oaxacan site, the legally required formation of a social development council was credited with the democratization of information about the budget-how much money the government had and how it was being spent. ${ }^{30}$ In one community in Sinaloa, a committee regularly coordinated activities for local development with municipal authorities - dances, rodeos, and raffles to raise money; materials to connect households with piped water; a police kiosk, and other such works. ${ }^{31}$

All of the research municipalities demonstrated some citizen activism at the submunicipal or community level. Organized by local residents, community improvement committees of various kinds reflected an apt understanding of effective ways to influence decisions about public investment. These organizations functioned with remarkably similar dynamics. First, they organized around a specific common interest. This was almost always an investment project and represented a significant local need-a road, potable water, or drainage ditches, for example. At times, the problem to be solved was one that had been identified by a community as a priority over a significant period of time. In one community, for example, the rainy season regularly brought flooding; in another, annual rains created an impassable stream that separated some residents from the main road to town; in yet another, residents had to travel long distances for emergency medical care and people had been known to die while being transported to the nearest hospital. In some cases, a very specific common interest brought a group together, as in the case of handicapped people in a Oaxacan municipality who organized to obtain a government-financed rehabilitation center. ${ }^{32}$

In its initial meeting, the committee would elect a president, secretary, and treasurer. Almost inevitably, those who emerged as leaders of an initiative were well recognized for their prior work on behalf of the community and were often those who had taken the initiative to mobilize the group at the outset. Those elected were also often those known to have a good reputation or good connections in the ayuntamiento-people who had acquired benefits for the community in the past or those who had stood firmly with a successful candidate during an election. It was the leadership's responsibility to represent the community to the municipality, and at times, to higher levels of government.

Community level committees selected similar strategies for approaching the municipality with their needs. The main focus of action was initially to draw up a petition that laid out the difficulties created by the problem and that asked the municipality for help in resolving it through a particular investment. The petition was signed by as many members of the community as possible. Very frequently, the committee would assess each member a small fee-usually from one to five dollars - to be used for transportation costs to send the leaders to the municipal seat to present the petition and then to follow up on a weekly basis to see what had become of it. Usually, they would take the petition directly to the mayor's office. While often this involved waiting for long periods of time in the mayor's anteroom before being granted an audience, this official would usually accept the petition, promise to give it priority, and then refer the group to the appropriate department for follow-up. 
Follow-up with the director of the department or the councilor who oversaw that department was an important part of the committee's subsequent strategy. This often meant repeated visits by the committee leadership to check on whether action had been taken by this person or when action was scheduled. Such follow-up activities were often sustained for weeks, months, and even years, and typically were financed by contributions from committee members. Persistence was essential, and met ruefully by some public officials. According to one, "It is impossible to escape from them. They always come to the town to investigate [what's happening] and demand attention for their projects." 33 While persistence often paid off, collective action strategies suggest the ways in which government priorities, promises, and responsiveness changed as incumbents in office changed; there was little institutional infrastructure that could be relied upon over time to take responsibility for delivering a particular benefit-initiatives often had to be re-started as governments at state and local levels changed hands.

From a strategic perspective, it was well understood that local contributions might mean a positive response from the government. As the principal of a school noted, "If you have money in your hand, the municipality is more likely to help. It shows you are committed and willing to work with the municipality." 34 In the same municipality, the legal affairs officer noted that if "you arrive with your petition — for a street, for example-and you have a good budget and 50,000 pesos, we see that you are willing to meet the municipality halfway. We can spend [the saved] money elsewhere." 35 At times, acquiring funds meant tapping into a variety of sources. In a municipality in Sinaloa, a group of migrants in the United States signed an agreement with the government to provide school scholarships for local children. ${ }^{36}$ Some projects came with explicit agreements that local residents would have to put up some of the money, as was the case with a health center approved for a community in Tamaulipas that required $\$ 15,000$ to be collected locally before construction could begin. ${ }^{37}$

A good example of the combination of local initiative and a facilitative municipality was the construction of a small bridge to join two parts of a community in Sinaloa. This community had long been divided by a gulch that could not be crossed by foot or motor traffic during the rainy season. For many years, community members had petitioned the municipality to put up a bridge, but had never been successful in their quest. Then, in 2002, community members elected a new committee to take on the task of building the bridge.

Led by their president, the committee acted shortly after a new municipal government came into office. Having decided that the bridge could be made of the kind of drainage pipes that were currently being used to build a sewage plant in the municipality, the committee petitioned the local agency in charge of constructing this plant. The agency agreed to donate two pipes, and then later two additional pipes when it was determined that two was not enough. The municipality was then asked to provide equipment to do the heavy work of shifting soil and laying the pipes. The committee sponsored dances and horse races and collected a five percent tax on beer sold in the community after certain hours to buy cement and other material and to pay for labor. Committee members 
also helped out in the construction and, reportedly, when others saw their leaders at this work, they joined in. Within a short time, the community was connected in good weather and bad. The municipal director of public works held up this community as an example of what could be accomplished when people worked together on local problems. ${ }^{38}$

Underpinning the strategic choices made by community improvement committees was the use of formal and informal networks to tap into the "right connection" for acquiring technical studies, approval, funding, equipment, and labor for the actual implementation of an investment. Thus, those who knew the mayor or who had been important in mobilizing people and votes for an election campaign or who were related in some way to influential public figures were often chosen to take the petition to town hall and follow up on it. Talking, negotiating, and invoking political support, the groups demonstrated good knowledge of how to find the right connections that would eventually result in their success. They formed alliances with officials willing to commit themselves to solutions, they worked around obstructionist local officials and appealed directly to state level officials, and they contributed from their own pockets to making something happen. Committees that were successful in gaining their objectives often did not stop at the municipal level but worked with contacts at the state level, at times even circumventing a local government that was distrusted or considered unresponsive.

Demanding Citizenship Rights. While local collective action built on strong traditions of petitioning and community organizing for benefits, there was scant evidence of citizens organizing around demands to improve the overall quality of government performance. Thus, while many communities mobilized around the need for potable water, a new road, a bridge, or drainage, they did not identify the quality of education delivered by the local school, the helpfulness of nurses and doctors at the local clinic, or the right to efficient service in the civil registry as issues around which to organize. How they were treated at town hall was a matter for complaints, but not for organization. Waiting in line, having to pay bribes, being refused service were conditions to be endured, even while many citizens expected that organizing around investment petitions would eventually pay off. Groups were primarily concerned about particular benefits, not about the more abstract idea of "good governance" as a right that could be demanded by citizens.

This does not mean that there were no initiatives to improve the quality of governance through citizen participation in the research municipalities. There were. But interestingly, these initiatives almost always originated in town hall, not in the demands, ideas, or actions of citizen groups. In several municipalities, for example, officials placed suggestion boxes in town hall and other localities so citizens could complain about services; these were often used to denounce particular officials who were judged not to be doing their jobs correctly. ${ }^{39}$ In a municipality in Yucatán, the local government created an office of citizen response, where residents could report water leaks, broken or burned out streetlights, problems with the police, and other such local concerns. ${ }^{40}$

In several municipalities, public departments carried out surveys to know which services were working well, which ones were experiencing problems, and how the municipal 
government's activities were viewed by its citizens. In many, "Citizen Wednesdays," "Citizen Mondays,” or "Saturdays in Your Neighborhood” took municipal officials outside of town hall to meet directly with constituents who had problems or complaints. When these kinds of accountability measures worked well, they did so because there were mechanisms in place to follow up and ensure that problems had been dealt with. Open sessions of the municipal council provided opportunities for greater transparency in some localities. As with other such innovations, these emerged at the initiative of public officials and agencies.

Current histories in the research municipalities revealed some instances in which citizens sought to hold officials accountable for their actions in ad hoc and sometimes violent ways. Thus, for example, the Citizen Movement of Ixtacamaxtitlán was formed in order to sack several mayors for poor performance, one after only six months in office. ${ }^{41}$ In the 1980s and 1990s, political movements ousted authoritarian political bosses in some municipalities. $^{42}$ In this way, some mayors and councilors felt under pressure from political society to improve the performance of local government. Nevertheless, a citizen's right to good governance was not one that was clearly articulated or acted upon by citizens in the research sites. Moreover, where non-electoral mechanisms of accountability did exist, they were much more likely to have been introduced by public officials than by citizen action.

Of course, demanding rights as citizens is a more difficult task than demanding public investments in infrastructure. The performance of teachers and schools, for example, was responsive to state level secretariats; nurses and doctors were hired and managed by state or national level institutions; road maintenance required expertise not always available to local citizens; garbage collection was a service that many were used to doing without. Moreover, demanding good performance as a right of citizenship entailed more ambiguous and on-going scrutiny than did mobilizing around interest in a particular infrastructure investment. It was clear when potable water was made newly available, but how could citizens identify "good governance?"

\section{Conclusions}

Three forms of government accountability to citizens - the use of the vote to sanction behavior, organizing to gain responsiveness to collective needs, and the capacity to demand rights of citizenship for fair and equitable treatment from government-are expected to improve through decentralization and democratization. Comparative research in municipalities in Mexico, however, suggests contextual factors that may limit the capacity of citizens to hold local governments accountable for their performance.

In the case of the municipalities in Mexico, more competitive elections and greater decentralization of responsibilities to local governments encouraged political parties to pay more attention to local contests and to democratize their internal procedures. Yet, a tradition of retail campaigning along with a prohibition on immediate re-election and an extensive turnover of appointed positions after elections weakened the ability of citizens to send a clear message to local governments and their officials about their expectations 
for improved performance. Common patterns in the research municipalities thus indicated the emergence of hotly contested local elections, something new in Mexico. The way in which campaigns were carried out, however, closely mimicked the kinds of political campaigns that were characteristic of Mexican politics in the past.

In contrast, citizen groups showed considerable sophistication and knowledge about how to extract benefits from government-especially how to get government to deliver on promises to provide public works. Using a fairly universal set of tools to influence public decision making, many were relatively successful in affecting the allocation of resources for particular projects and communities. The means they used were familiar ones, petitioning and invoking networks of influentials, often through time-tested forms of clientelism. Their objectives were to obtain tangible benefits that could be provided in the short term; not surprisingly, they often found politicians ready to respond to their requests for these types of projects - these investments provided concrete evidence of actions that were bringing benefits to the communities.

In the municipalities studied, most citizens had an extractive relationship with government rather than one based on their rights as citizens to demand good performance. Parent groups were not active in demanding that schools perform effectively or that teachers show up for work regularly; committees formed to plan municipal investments or to oversee the construction of a clinic or a road did not subsequently oversee the management of the clinic or the maintenance of the road. When garbage collection services failed, there was little evidence that citizens organized to demand their improvement. Moreover, even with investment projects, when local officials were unresponsive, citizen groups went elsewhere rather than demand more accountability locally.

Thus, the effectiveness of civic action in Mexico was limited by the weakness of political and administrative institutions. In the case of extracting benefits, the response to petitions from local communities depended primarily on the decisions of mayors, councilors, and public works officials rather than on enforceable institutional commitments over time. When administrations changed, community improvement committees often had to start all over again to gain support from the local government-a paper trail of commitments from the past was not an effective way to ensure that projects could be sustained across administrations. In the case of citizenship rights to effective government, mechanisms for ensuring it often depended on the willingness of public officials to create and maintain them. The looseness of local institutions was a significant constraint on citizen engagement in monitoring government performance.

Nevertheless, the extent to which civic organizations became mobilized and pressured government to deliver on promises for public works and social infrastructure undoubtedly contributed to the delivery of these services in all the municipalities. The on-going petitioning, lobbying, and reminders of commitments made to specific communities kept many public officials from ignoring their responsibilities and promises. These activities also kept municipal leaders from assuming full control of resource allocation decisions. While there were few institutional constraints on decisions about the distribution of 
public investments, the mobilization of community groups acted to shape these allocations in ways that would have been different, absent these organizations.

Moreover, the increased importance of competitive elections in Mexico's municipalities also provided opportunities for new leadership groups to reach public office, some of whom had strong commitments to introducing more participatory and responsive forms of governance. As experience with more democratic local elections increases, it may well be that ideas about the right to good performance will become more prominent. Additionally, the accountability mechanisms introduced in a number of municipalities from the top down may become more institutionalized over time and thus provide more focus on good performance as an everyday expectation.

This distinction in terms of civil society activism in local government is an important one in the design of development policies, programs, and projects and in understanding the impact of decentralization. Currently popular forms of encouraging participation in local decision making — such as organizing groups to help plan municipal investments-may in fact help to restrict citizen input to tasks of petitioning, making connections, lobbying, and finding ad hoc methods to influence government, rather than encouraging the development of a culture of accountability, of a sense that citizens have a right to demand effective government. That culture can perhaps be more effectively built by changes that make the vote a more effective means for delivering messages of approval or disapproval of performance and encouraging understanding of how democratic rights can be exercised. 


\title{
Notes
}

\begin{abstract}
${ }^{1}$ This paper draws extensively on Grindle 2007.
${ }^{2}$ The literature on decentralization and accountability is extensive. Many scholars trace arguments about local government and the ability of citizens to hold government accountable to Alexis de Toqueville (1848). For more recent discussions, see Abers 1998; Alatas, Pritchett, and Wetterberg 2002; Baiocchi 2001; Beer 2003; Blair 2000; Campbell 2005; Crook and Manor 1998; Eaton 2004; Faletti 2003; Fung 2004; Heller 2001; Montero and Samuels 2004; O’Neill 2003; Oxhorn, Tulchin, and Selee 2004; Putnam 1993; Schönwälder 1997; Tendler 1997. The discussion of three forms of accountability presented in the paper draws on this literature. See also Grindle 2007 for more discussion.
\end{abstract}

${ }^{3}$ See Stoner-Weiss 1997 and Snyder 2001 on this methodology. The states were Guanajuato, Oaxaca, Puebla, Sinaloa, Tamaulipas, and Yucatán. In 2000, municipalities between 25,000 and 100,000 inhabitants included 23.6 percent of all local governments in Mexico and 25.3 percent of its population; their average population was 46,516 (INEGI 2000). These municipalities were large enough to have substantial responsibilities and significant resources for attending to them, yet small enough to facilitate understanding complex political, administrative, and fiscal interactions.

${ }^{4}$ Collectively, 569 individuals were interviewed, including 51 current and former mayors, 113 councilors, 229 local public managers, 98 community leaders and important citizens, 26 local party officials, 48 state and federal level officials, as well as a number of academic experts. Orazio Bellettini, Karla Breceda, Alexi Canaday-Jarrix, Elizabeth Coombs, Xochitl Leon, and Alberto Saracho-Martínez, graduates of the Kennedy School of Government at Harvard University, and Sergio Cárdenas-Denham, of the Harvard Graduate School of Education, carried out the research. In addition, Naomi Walcott, Elizabeth Gewurz Ramírez, and Emanuel Garza Fishburn assisted in the research.

${ }^{5}$ The Municipal Census of 2002 reported that Mexico contained 2,429 municipalities; their size and population varied greatly The largest municipality is one that extends for almost 52,000 square kilometers in the state of Baja California; the smallest measured just 4.3 square kilometers in the state of Tlaxcala. Similarly, populations ranged from 1.65 million people in a municipality in the state of Jalisco to 109 people in a Oaxacan municipality.

${ }^{6}$ On decentralization in Mexico, see Beer 2003; Bruhn 1999; Cabrera Mendoza 2003; Cornelius, Eisenstadt, and Hindley 1994; Fox and Aranda 1996; García del Castillo 2003; Grindle 2007; Merino 2004; Mizrahi 2004; Rodríguez 1997; Santín del Río 2004; Ward, Rodríguez, and Cabrero Mendoza 1999.

${ }^{7}$ The number of councilors is dependent on the population of the municipality and is determined by state law. In the thirty research municipalities, councils ranged from 6 to 22 elected officials, and had an average of 12 councilors. Depending on the municipality, the council met once a week, every two weeks, once a month, or irregularly. In most municipalities, each councilor had oversight responsibility for one or more public departments. There are important exceptions to this general panorama of municipal government. In states in which there are significant indigenous populations, local governments can legally be governed by traditional rules, known as usos y costumbres (traditions and customs). In such circumstances, local governments are generally constituted through large community meetings in which participants nominate individuals for particular office and then vote by voice, show of hands, or lining up behind particular nominees. Sometimes usos y costumbres involves selecting leaders by acclamation and there are a few municipalities in which a council of elders determines the leadership of local government. Parties may or may not play a role in these local decision making processes.

${ }^{8}$ Opposition parties began winning elections at the local level in the 1980s. In 1989, the first governor from an opposition party won election (although earlier in the decade, a number of other opposition candidates at this level may have fallen victim to electoral fraud). 
${ }^{9}$ Ward 1995:141. Local politics were controlled by party bosses, or caciques, who used their power in the local economy to marshal or coerce votes for their PRI patrons at state and national levels. In the words of a journalist in one cacique-ridden state, one such local boss "used the municipality's money as if it were his own” (Interview, June 22, 2004, San Pedro Cholula, Puebla). Before 1980, explained a mayor, "there was a person who decided what needed to be done. This person belonged to the PRI and he was the person who communicated with the state and federal governments about who would be the next candidate, and consequently, the mayor....In those times there were no [real] elections; he named [mayors] with the dedazo (literally, “the big finger”; Interview, July 7, 2004, San Juan Guichicovi, Oaxaca.)

${ }^{10}$ The PAN was created in 1939 and had been successful in winning a number of state and local electoral contests in the 1980s and 1990s. The PRD was established in 1989 (from its predicessor, the Frente Nacional Democrático, established in 1988); its capacity to win numbers of local elections has been less than that of the PAN, but it won control over the government of Mexico City in 1997, one of the world's largest cities.

${ }^{11}$ In the thirty research municipalities, locally generated resources accounted for an average of only 11 percent of total funding.

${ }^{12}$ Interview, June 23, Santo Domingo Tehuantepec, Oaxaca.

${ }^{13}$ Interviews, June 18, 2004, González, Tamaulipas; June 24, 2004, Santo Domingo Tehuantepec, Oaxaca.

${ }^{14}$ Interview, June 24, 2004, Santo Domingo Tehuantepec, Oaxaca.

${ }^{15}$ Interview, June 21, 2004, González, Tamaulipas.

${ }^{16}$ Interview, July 27, 2004, Acatlán de Pérez Figueroa, Oaxaca

${ }^{17}$ Interview, August 4, 2004, Miguel Aleman, Tamaulipas.

${ }^{18}$ Interview, June 26, 2004, San Pedro Cholula, Puebla.

${ }^{19}$ Interview, June 23, 2004, Santo Domingo Tehuantepec, Oaxaca.

${ }^{20}$ For example, a federal employee related, "My boss at SEDESOL is running for mayor of a small municipality outside Ciudad Victoria. I'm helping him in the campaign and he'll give me a job in the administration. I'll just go every two weeks to sign for my check, so I can keep my job at SEDESOL." Interview, July 17, 2004, Tula, Tamaulipas.

${ }^{21}$ Interviews, July 17, 2004, Acatlán de Pérez Figueroa, Oaxaca; August 6, 2004, Santiago Pinotepa Nacional, Oaxaca; July 5, 2004, Manuel Doblado, Guanajuato.

${ }^{22}$ Interviews, July 15, 2004, Tula, Tamaulipas; August 19, 2004, Uman, Yucatán.

${ }^{23}$ Interviews, July 8, 2004, Manuel Doblado, Guanajuato; June 22, 2004, Abasolo, Guanajuato; August 19, 2004, Uman, Yucatán.

${ }^{24}$ Interview, June 21, 2004, González, Tamaulipas.

${ }^{25}$ A general overview of civic associations in Mexico is found in Puga 2004. According to this author, associational life in Mexico became stronger when economic crises robbed governments of resources that could be distributed to keep the political peace, when presidents became less powerful leaders in the country, when political competition increased, and when horizontal associations simultaneously grew stronger (Puga 2004:5). 
${ }^{26}$ The social development fund program known initially as PRONASOL and later as SOLIDARIDAD was an important innovation in this regard.

${ }^{27}$ Many individual programs required local participatory mechanisms, a component of development projects that could be traced back to community development programs in the 1960s and 1970s and that again grew popular in the 1990s and 2000s. In 2003, the Law of Social Development guaranteed that programs focused on social development would be accompanied by "social participation forms in the formulation, implementation, evaluation, and control of social development programs" as a way of promoting the organizational capacity of Mexican society. Quoted in Puga 2004:11.

${ }^{28}$ Paraphrase of interview, June 6, 2004, Rosario, Sinaloa.

${ }^{29}$ Interview, August 11, 2004, Santiago Pinotepa Nacional, Oaxaca.

${ }^{30}$ Interview, June 19, 2004, Santo Domingo Tehuantepec, Oaxaca.

${ }^{31}$ Interview, July 8, 2004, Salvador Alvarado, Sinaloa.

${ }^{32}$ Interview, June 20, 2004, Acatlán de Pérez Figueroa, Oaxaca.

${ }^{33}$ Interview, June 21, 2004, Santo Domingo Tehuantepec, Oaxaca.

${ }^{34}$ Interview, June 16, 2004, González, Tamaulipas.

${ }^{35}$ Interview, June 17, 2004, González, Tamaulipas.

${ }^{36}$ Interview, July 6, 2004, Mocorito, Sinaloa. On the role of home town associations (HTAs) in local development, see Levitt (2001).

${ }^{37}$ Interview, August 26, 2004, San Fernando, Tamaulipas.

${ }^{38}$ Interview, July 27, 2004, Salvador Alvarado, Sinaloa.

${ }^{39}$ Interview, July 22, 2004, Chignahuapan, Puebla.

${ }^{40}$ Interview, October 17, 2004, Oxkutzcab, Yucatán.

${ }^{41}$ Interview, July 22, 2004, Ixtacamaxtitán, Puebla.

${ }^{42}$ Interview, July 7, 2004, San Juan Guichicovi, Oaxaca.

\section{References}

Abers, Rebecca. 1998. "From Clientelism to Cooperation: Local Government, Participatory Policy, and Civic Organizing in Pôrto Alegre, Brazil.” Politics and Society, Vol. 26, no. 4.

Alatas, Vivi, Lant Pritchett, and Anna Wetterberg. 2002. "Voice Lessons: Local Government Organizations, Social Organizations, and the Quality of Local Governance.” Policy Research Working Paper No. 2981. Washington, D.C.: The World Bank (March).

Baiocchi, Gianpaolo. 2001. "Participation, Activism, and Politics: The Pôrto Alegre Experiment and Deliberative Democratic Theory.” Politics and Society. Vol. 29, no. 1. 
Barzelay, Michael. 2001. The New Public Management: Improving Research and Policy Dialogue. Berkeley: University of California Press.

Beer, Caroline C. 2003. Electoral Competition and Institutional Change in Mexico. Notre Dame, IN: University of Notre Dame Press.

Bruhn, Kathleen. 1999. “PRD Local Governments in Michoacán: Implications for Mexico’s Democratization Process.” In Wayne A. Cornelius, Todd A. Eisenstadt, and Jane Hindley, eds., Subnational Politics and Democratization in Mexico. La Jolla: Center for U.S.-Mexican Studies, University of California, San Diego.

Cabrero Mendoza, Enrique. Ed. 2003. Políticas públicas municipales: Una agenda en construcción. Mexico City: Miguel Angel Porrua.

Campbell, Tim. 2005. The Quiet Revolution: Decentralization and the Rise of Political Participation in Latin America's Cities. Pittsburgh, PA: University of Pittsburgh Press.

Wayne A Cornelius, Todd A. Eisenstadt, and Jane Hindley, eds. 1999. Subnational Politics and Democratization in Mexico. La Jolla, CA: Center for U.S. Mexican Studies , University of California at San Diego.

Crook, Richard C., and James Manor. 1998. Democracy and Decentralisation in South Asia and West Africa: Participation, Accountability and Performance. Cambridge: Cambridge University Press.

Eaton, Kent. 2004. Politics beyond the Capital: The Design of Subnational Institutions in South America. Stanford, CA: Stanford University Press.

Faletti, Tulia G. 2003. "Of Presidents, Governors, and Mayors: The Politics of Decentralization in Latin America." Paper prepared for the 2003 meeting of the Latin American Studies Association, Dallas, Texas, March 27-29.

Fox, Jonathan, and Josefina Aranda. 1996. Decentralization and Rural Development in Mexico: Community Participation in Oaxaca's Municipal Funds Program. La Jolla: Center for U.S.-Mexican Studies, Monograph Series No. 42, University of California, San Diego.

Fung, Archon. 2004. Empowered Participation: Reinventing Urban Democracy. Princeton, N.J.: Princeton University Press.

García del Castillo, Rodolfo. 2003. "La política de servicios municipales en México: Casos y tendencies recientes.” In Enrique Cabrero Mendoza, ed., Políticas públicas municipales: Una agenda en construcción. Mexico City: Miguel Angel Porrua.

Grindle, Merilee S. 2007. Going Local: Decentralization, Democratization, and the Promise of Good Governance. Princeton, N.J.: Princeton University Press.

Heller, Patrick. 2001. "Moving the State: The Politics of Democratic Decentralization in Kerala, South Africa, and Porto Alegre.” Politics and Society, Vol 29, no. 1.

Manor, James. 1999. The Political Economy of Democratic Decentralization. Washington, D.C.: The World Bank.

Merino, Mauricio. 2004. "Los gobiernos municipales de México: El problema del deseño institucional.” Documento de Trabajo No. 145. Mexico, D.F.: CIDE. 
Mizrahi, Yemile. 2004. “Twenty Years of Decentralization in Mexico: A Top-Down Process.” In Philip Oxhorn, Joseph S. Tulchin, and Andrew D. Seele, eds., Decentralization, Democratic Governance, and Civil Society in Comparative Perspective: Africa, Asia, and Latin America. Baltimore, MD: The Johns Hopkins University Press.

Montero, Alfred P., and David J. Samuels, eds. 2004. Decentralization and Democracy in Latin America. Notre Dame, IN: University of Notre Dame Press.

O’Neill, Kathleen. 2003. "Decentralization as an Electoral Strategy.” Comparative Political Studies. Vol. 36 (November).

Oxhorn, Philip, Joseph S. Tulchin, and Andrew D. Selee, eds. 2004. Decentralization, Democratic Governance, and Civil Society in Comparative Perspective: Africa, Asia, and Latin America. Baltimore, MD. The Johns Hopkins University Press.

Puga, Cristina. 2004. “Associations and Governance in Mexico.” Paper prepared for the $25^{\text {th }}$ International Congress of the Latin American Studies Association. Las Vegas, NV, October 7-9.

Putnam, Robert. 1993. Making Democracy Work: Civic Traditions in Modern Italy. Princeton, N.J.: Princeton University Press.

Rodríguez, Victoria E. 1997. Decentralization in Mexico: From Reforma Municipal to Solidaridad to Nuevo Federalismo. Boulder, CO: Westview Press.

Santín del Río, Leticia. 2004. "Decentralization and Civil Society in Mexico.” In Philip Oxhorn, Joseph S. Tulchin, and Andrew D. Selee, eds., Decentralization, Democratic Governance, and Civil Society in Comparative Perspective: Africa, Asia, and Latin America. Baltimore, MD: The Johns Hopkins University Press.

Schönwälder, Gerd. 1997. "New Democratic Spaces at the Grassroots? Popular Participation in Latin American Local Government.” Development and Change, Vol. 28.

Snyder, Richard. 2001. “Scaling Down: The Subnational Comparative Method.” Studies in Comparative International Development, Vol 36, no. 1.

Tendler, Judith. 1997. Good Governance in the Tropics. Baltimore, MD: The Johns Hopkins University Press.

Toqueville, Alexis De. 1848. Democracy in America. 1988 edition. New York: Perennial Library.

Ward, Peter M. 1995. "Policy Making and Policy Implementation among Non-PRI Governments: The PAN in Ciudad Juárez and Chihuahua.” In Victoria Rodríguez, and Peter M. Ward, eds. Opposition Government in Mexico. Albuquerque: University of New Mexico Press.

Ward, Peter M., and Victoria Rodríguez, with Enrique Cabrero Mendoza 1999. The New Federalism and State Government in Mexico: Bringing the State Back In. Austin, TX: U.S.-Mexican Policy Report No. 9, Lyndon B. Johnson School of Public Affairs, The University of Texas at Austin. 